\title{
Upaya Meningkatkan Prestasi Belajar Pendidikan Agama Islam melalui Model Eksperimen
}

\author{
Umi Cholifah \\ UPK Lumbir Banyumas \\ Butulan, Lumbir, Kec. Lumbir, Kabupaten Banyumas, Jawa Tengah \\ Email: bdmartono7@gmail.com
}

\begin{abstract}
ABSTRAK
Tindakan perbaikan pembelajaran ini dilaksanakan melalui Penelitian Tindakan Kelas( PTK) dengan menerapkan metode " Model Pembelajaran Eksperimen ", pada mata pelajaran Pendidikan Agama Islam dengan materi pokok Mengenal Ketentuan Salat. Pelaksanaan PTK ini mengikuti langkah-langkah yang dikemukakan oleh IGAK Wardhani yang tahapannya meliputi : perencanaan ( planning ), pelaksanaan ( acting ), observasi ( observasing ) dan refleksi ( reflecting) atau evaluasi . Tahapan - tahapan berdaur dan membentuk siklus. PTK ini pelaksanaanya secara berkolaborasi antara peneliti, pengamat dan Teman Sejawat sebagai supervisor. Proses tindakan perbaikan materi Pendidikan Agama Islamdengan menggunakan metode" Model Pembelajaran Eksperimen ") minat dan keterlibatan serta keaktifan siswa mengalami peningkatan, siswa semangat melakukan kerja kelompok, berdiskusi maupun menjawab pertanyaan peneliti, 2 ) hasil prestasi atau ketuntasan belajar meningkat dari $31,25 \%$ pada siklus awal menjadi $62,5 \%$ pada siklus I dan mencapai $87,5 \%$ pada siklus II.
\end{abstract}

Kata kunci: Model Pembelajaran Eksperimen, PTK, Pendidikan Agama Islam.

\section{ABSTRACT}

This learning improvement action was carried out through Classroom Action Research (CAR) by applying the "Experimental Learning Model" method, in Islamic Religious Education subjects with the subject matter Knowing the Prayer Principles. The implementation of the CAR follows the steps put forward by IGAK Wardhani whose stages include: planning, acting, observing and reflecting or evaluating. Stages - the stages of recycling and forming cycles. PTK is implemented collaboratively between researchers, observers and peers as supervisors. The process of action to improve Islamic Religious Education material by using the method "Experimental Learning Model") the interest and involvement and activeness of students has increased, students are enthusiastic about doing group work, discussing or answering researchers' questions, 2) achievement or completeness learning outcomes increased from $31.25 \%$ in the initial cycle became $62.5 \%$ in the first cycle and reached $87.5 \%$ in the second cycle.

Keywords: Experimental Learning Model, PTK, Islamic Education.

\section{PENDAHULUAN}

Guru yang memandang anak didik sebagai pribadi yang berbeda dengan anak didik lainnya akan berbeda dengan guru yang memandang anak didik sebagai makhluk yang sama dan tidak ada perbedaan dalam segala hal. Maka adalah penting meluruskan pandangan yang keliru dalam menilai anak didik. Sebaiknya guru memandang anak didik sebagai individu dengan segala perbedaannya, sehingga mudah melakukan pendekatan 
dalam pengajaran. Kualitas pembelajaran ditentukan oleh interaksi komponen-komponen dalam sistemnya. Yaitu tujuan, bahan ajar (materi), anak didik, sarana, media, metode, partisipasi masyarakat, performance sekolah, dan evaluasi pembelajaran (Moh, Shochib, 1998). Performance sekolah, dan evaluasi pembelajaran (Moh, Shochib, 1998). Optimalisasi komponen ini, menentukan kualitas (proses dan produk) pembelajaran. Upaya yang dapat dilakukan oleh pendidik adalah melakukan analisis tentang karakteristik setiap komponen dan mensinkronisasikan sehingga ditemukan konsistensi dan keserasian di antaranya untuk tercapainya tujuan pembelajaran. Karena pembelajaran mulai dari perencana, pelaksanaan dan evaluasinya senantiasa merujuk pada tujuan yang diharapkan untuk dikuasai atau dimiliki oleh anak didik baik instructional effect (sesuai dengan tujuan yang dirancang) maupun nurturrant effect (dampak pengiring) (Moch. Shochib: 1999). Sejalan dengan inovasi pembelajaran akhir-akhir ini termasuk di Sekolah Dasar, yaitu: Eksperimen. Interaksi belajar mengajarnya menuntut anak didik untuk aktif, kreatif dan senang yang melibatkan secara optimal mental dan fisik mereka. Tingkat keaktifan, kreatifitas, dan kesenangan mereka dalam belajar merupakan rentangan kontinum dari yang paling rendah sampai yang paling tinggi. Tetapi idealnya pada kontinum yang tertinggi baik pelibatan aspek mental maupun fisik anak didik. Oleh karena itu, interaksi belajar mengajar dengan paradigma Eksperimen menuntut anak: Berdasarkan problem based learning, authentic instruction, inquiry based learning, project based learning, service learning, and cooperative learning. Pola interaksi yang mampu mengemas hal tersebut dapat mengubah paradigma pembelajaran aktif menjadi paradigma pembelajaran reflektif.

Dengan interaksi pembelajaran reflektif dapat membuat anak didik untuk menjadikan hasil belajar sebagai referensi refleksi kritis tentang dampak ilmu pengetahuan dan teknologi terhadap masyarakat; mengasah kepedulian sosial, mengasah hati nurani, dan bertanggungjawab terhadap karirnya kelak. Kemampuan ini dimiliki anak didik, karena dengan pola interaksi pembelajaran tersebut, dapat membuat anak didik aktif dalam berfikir (mind-on), aktif dalam berbuat (hand-on), mengembangkan kemampuan bertanya, mengembangkan kemampuan berkomunikasi, dan membudayakan untuk memecahkan permasalahan baik secara personal maupun sosial. Agar hasil ini dapat optimal, guru dituntut untuk mengubah peran dan fungsinya menjadi fasilitator, mediator, mitra belajar anak didik, dan evaluator. Ini berarti, guru harus menciptakan interaksi pembelajaran yang demokratis dan dialogis antara guru dengan anak didik, dan anak didik dengan anak didik (Moh. Shochib: 1999; dan Paul Suparno dkk: 2001). 
Dengan interaksi pembelajaran yang mengemas nilai-nilai tersebut dapat membuat pembelajaran lingking (link and math atau life skill) dan delinking(pemutusan lingkungan negatif), diversifikasi kurikulum, pembelajaran kontekstual, kurikulum berbasis kompetensi, dan otonomi pendidikan pada tingkat sekolah taman kanak-kanak dengan manajemen berbasis sekolah, dan bertujuan untuk mengupayakan fondasi dan mengembangkan anak untuk memiliki kemampuan yang utuh yang disebut: Pendidikan Anak Seutuhnya (PAS). Pada dasarnya dalam kehidupan suatu bangsa, faktor pendidikan mempunyai peranan yang sangat penting untuk menjamin perkembangan dan kelangsungan hidup bangsa tersebut. Secara langsung maupun tidak langsung pendidikan adalah suatu usaha sadar dalam menyiapkan pertumbuhan dan perkembangan anak melalui kegiatan, bimbingan, pengajaran dan pelatihan bagi kehidupan dimasa yang akan datang. Tentunya hal ini merupakan tanggung jawab bersama antara pemerintah, anggota masyarakat dan orang tua. Untuk mencapai keberhasilan ini perlu dukungan dan partisipasi aktif yang bersifat terus menerus dari semua pihak. Guru mengemban tugas yang berat untuk tercapainya tujuan pendidikan nasional yaitu meningkatkan kualitas manusia Indonesia, manusia seutuhnya yang beriman dan bertakwa terhadap Tuhan Yang Maha Esa, berbudi pekerti luhur, berkepribadian, berdisiplin, bekerja keras, tangguh, bertanggung jawab, mandiri, cerdas dan terampil serta sehat jasmani dan rohani, juga harus mampu menumbuhkan dan memperdalam rasa cinta terhadap tanah air, mempertebal semangat kebangsaan dan rasa kesetiakawanan sosial. Sejalan dengan itu pendidikan nasional akan mampu mewujudkan manusia-manusia pembangunan dan membangun dirinya sendiri serta bertanggung jawab atas pembangunan bangsa. Depdikbud (1999). Berhasilnya tujuan pembelajaran ditentukan oleh banyak faktor diantaranya adalah faktor guru dalam melaksanakan proses belajar mengajar, karena guru secara langsung dapat mempengaruhi, membina dan meningkatkan kecerdasan serta keterampilan siswa. Untuk mengatasi permasalahan di atas dan guna mencapai tujuan pendidikan secara maksimal, peran guru sangat penting dan diharapkan guru mampu menyampaikan semua mata pelajaran yang tercantum dalam proses pembelajaran secara tepat dan sesuai dengan konsep-konsep mata pelajaran yang akan disampaikan. Model Pembelajaran Eksperimen merupakan sebuah proses di kelas yang telah menjadi daya tarik tersendiri bagi para peneliti praktik pembelajaran sejak tahun 1970-an hingga sekarang ini. Secara konsisten, para peneliti telah menemukan bukti-bukti bahwa ketika guru mampu menggunakan prosedur Model Pembelajaran Eksperimen yang efektif ternyata dapat meningkatkan prestasi belajar siswanya. Adapun rumusan masalah dalam Penelitian Tindakan Kelas ini 
,yaitu Bagaimanakah peningkatan hasil belajar Pendidikan Agama Islam tentang Mengenal Ketentuan Salat pada siswa kelas IV SDN Karangwangkal setelah mengikuti Pembelajaran Eksperimen ?. Tujuan dari penelitian perbaikan pembelajaran ini adalah untuk meningkatkan hasil belajar Pendidikan Agama Islamtentang Mengenal Ketentuan Salat pada siswa kelas IV SDN Karangwangkal Unit Kecamatan Lumbir melalui Pembelajaran Eksperimen.

Banyak pengertian belajar yang dikemukakan oleh para ahli, salah satunya menurut Gagne (1984), bahwa belajar adalah suatu proses di mana suatu organisme berubah prilakunya sebagai akibat pengalaman ( Strategi Belajar Mengajar, 2004:2.3), Juga menurut Gagne (1984) belajar dapat didefinisikan sebagai suatu proses di mana suatu organisme berubah akibat pengalaman. Dengan menjalani proses, akan terjadi perubahan dalam diri seseorang, apabila sebelum menjalani proses belajar seseorang belum mempunyai pengetahuan akan sesuatu hal dan belum mepunyai keterampilan tertentu dan bersikap tidak menolak pada infomasi yang diberikan, maka setelah menjalani proses belajar Ia akan menjadi tahu atau lebih tahu, dan menjadi trampil atau lebih trampil. Proses perubahan yang terjadi harus relative bersifat menetapkan tidak terjadi hanya pada saat ini nampak, tetapi juga pada perilaku yang mungkin terjadi pada masa mendatang. Berdasarkan uraian di atas, maka proses pengajaran dimaknai sebagai suatu proses terencana dan memiliki tujuan tertentu, baik yang ditetapkan oleh siswa maupun oleh pengajar, sehingga individu yang terlibat dalam proses tersebut akan mengalami perubahan sebagaimana yang diharapkan. Dari artian ini proses pengajaran merupakan proses yang dengan sengaja dirancang sedemikian rupa sesuai dengan tujuan yang telah ditetapkan untuk dapat mengubah perilaku siswa. Dalam proses belajar mengajar pada mata pelajaran PAI , guru hendaknya menyampaikan atau mengalihkan pesan atau pengetahuan yang diyakini berguna bagi siswa dikemudian hari untuk dipelajari dan difahami. Selain itu, dalam proses belajar mengajar, guru juga menyampaikan cara efektif yang dapat dilakukan siswa untuk dapat memahami atau mempelajari materi yang disampaikan, serta memberikan Eksperimen mengenai perkembangan proses belajar yang dijalani siswa. Dari sisi siswa juga diharapkan agar mereka dapat menyampaikan informasi kepada guru bahwa materi yang disampaikan guru, tidak atau belum dapat difahami atau dimengerti, sehingga dapat dilakukan pengulangan proses belajar. Keberhasilan proses pembelajaran tidak terlepas dari cara pendidik mengajar dan peserta didik belajar, sebab baik tidaknya proses pembelajaran dapat dilihat dan dirasakan oleh pendidik dan peserta didik sendiri. Proses belajar mengajar dikatakan berhasil apabila ada perubahan pada diri peserta didik, 
menyangkut pengetahuan sikap dan keterampilan, dan juga didalam proses pembelajaran peserta didik harus menunjukan kegairahan belajar yang tinggi, semangat kerja yang besar dan percaya pada diri sendiri (Ade Rukmana dan Asep Suryana, 2006: 13). Untuk mendapatkan Eksperimen dari anak didik diperlukan beberapa teknik yang sesuai dan tepat dengan diri anak didik sebagai makhluk individual. Berikut ini beberapa teknik untuk mendapatkan Eksperimen dair anak didik (Syaiful Bahri D dan Aswan Zain, 2006:143) :

1) Memancing Apersepsi Anak

a. Memanfaatkan Taktik Alat Bantu yang Akseptabel

b. Memilih Bentuk Motivasi yang Akurat

c. Menggunakan Metode yang Bervariasi

d. Berdasarkan analisis teori-teori di atas, dalam memperbaiki hasil belajar siswa terutama mata pelajaran PAI , penelitian ini difokuskan untuk meningkatkan hasil belajar siswa dengan menggunakan metode Eksperimen.

e. Untuk mengetahui berhasil tidaknya seorang guru dalam menyampaikan materi pembelajaran bisa dilihat dari hasil kerja siswa. Untuk itu guru haru mengadakan penilaian, dengan mengadakan penilaian, guru dapat melihat sejauh mana kemampuan siswa dalam menyerap materi pembelajaran. Hopkins dan Stanley (1981) menyatakan bahwa "Ada kelompok pelaku pendidikan yang harus memperhatikan hasil penilaian. Kelompok tersebut adalah (guru, anak didik dan orang tua murid)".

f. Dalam melaksanakan penilaian, ada beberapa cara, misalnya dengan tes lisan atau tes tertulis. Tes lisan bisa berupa tanya jawab langsung dengan siswa, sedangkan tes tulis ada uraian, essay dan pilihan ganda. Guru bisa mengambil satu diantara cara penilaian tersebut, bisa juga digunakan semua seperti ulangan semester.

\section{METODE PENELITIAN}

Prosedur penelitian ini dilakukan dengan menggunakan metode Penelitian Tindakan Kelas (PTK). Perbaikan pembelajaran yang merupakan prosedur PTK ini diawali dengan proses kesadaran seorang guru mengenai adanya masalah yang terjadi dalam pembelajaran yang dilaksanakan.I.G.A.K. Wardhani dan Kuswaya Wihardit (2014:4) menyatakan bahwa "penelitian tindakan kelas adalah penelitian yang dilakukan oleh guru di dalam kelasnya sendiri melalui refleksi diri dengan tujuan untuk memperbaiki kinerjanya sebagai guru, sehingga hasil belajar anak didik menjadi meningkat". Penelitian tindakan kelas terdiri atas rangkaian empat kegiatan yang dilakukan dalam siklus berulang. Empat kegiatan utama yang ada pada setiap siklus yaitu perencanaan tindakan (planning), 
pelaksanaan tindakan (acting), melakukan pengamatan (observing), dan melakukan refleksi (reflecting). Hubungan keempat kegiatan tersebut dapat dilihat pada Gambar 3.3 sebagai berikut.

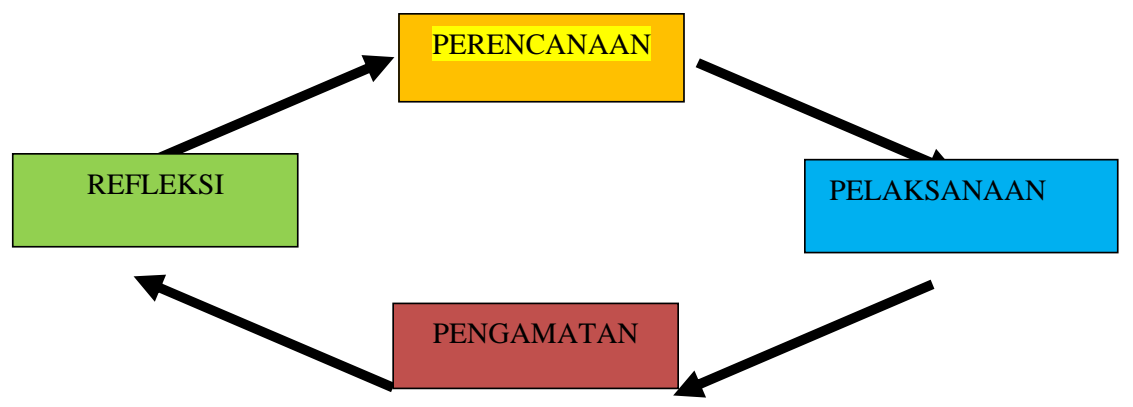

Gambar 1. Tahap-tahap dalam Penelitian Tindakan Kelas

\section{HASIL DAN PEMBAHASAN}

Apabila sudah diketahui letak keberhasilan dan hambatan dari tindakan yang dilaksanakan pada siklus pertama tersebut, peneliti bersama teman sejawat (observer) menentukan rancangan untuk siklus kedua. Pada tahap pengamatan siklus I, data yang diperoleh berupa rekapitulasi nilai tes formatif pembelajaran seperti yang tersaji pada Tabel 4.2 sebagai Pada prasiklus, siswa yang tuntas sebanyak 9 siswa atau 31,25\% dengan nilai rata-rata yang dicapai sebesar 56,5. Pada siklus I, siswa yang tuntas sebanyak 14 siswa atau $70 \%$ dengan nilai rata-rata yang dicapai sebesar 63. Data tersebut juga dapat dilihat melalui diagram lingkaran pada Gambar 4.2 sebagai berikut.

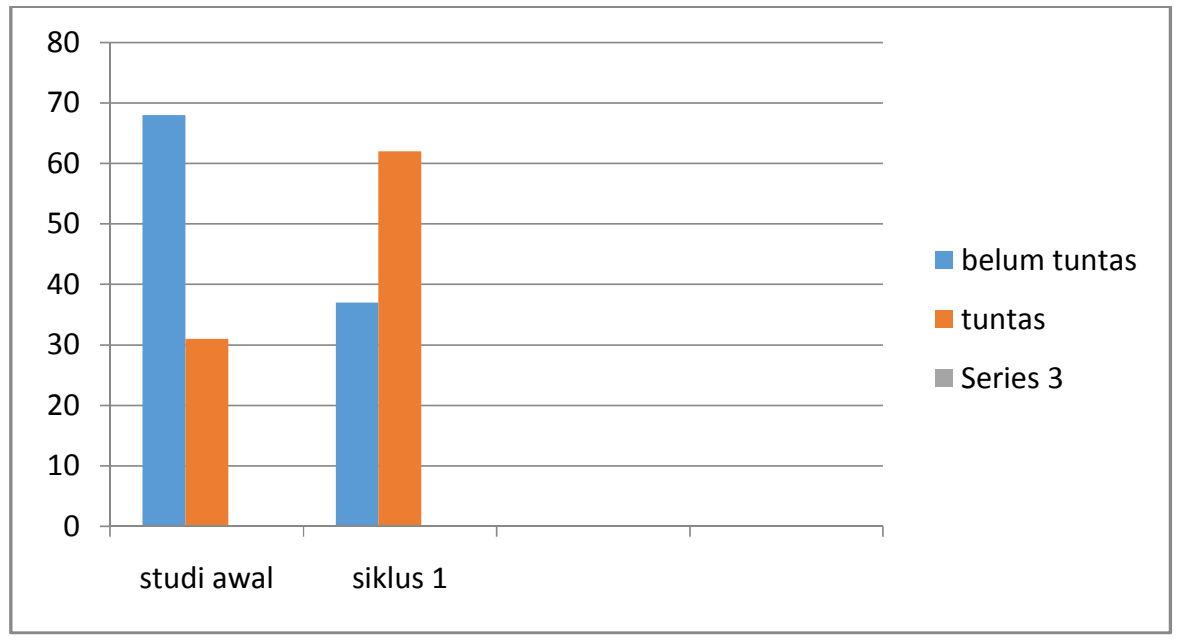

Gambar 2. Ketuntasan Hasil Prestasi Belajar Siklus I

Pada siklus I ini, ketuntasan belajar siswa dalam pembelajaran Pendidikan Agama Islam Kompetensi dasar Menyebutkan hal-hal yang membatalkan salatmelalui model 
Penerapan Model Pembelajaran Eksperimen mencapai 62,5\%. Hal ini masih di bawah kriteria ketuntasan, yaitu minimal 80\% dari jumlah siswa. Dengan demikian, maka akan dilaksanakan perbaikan pembelajaran kembali pada siklus II dengan mengubah benda yang didemonstrasikan.

1) Pada siklus I, siswa yang tuntas sebanyak 10 siswa atau $62,5 \%$ dengan nilai rata-rata yang dicapai sebesar 65,2.

2) Pada siklus II, siswa yang tuntas sebanyak 14 siswa atau $87,5 \%$ dengan nilai rata-rata yang dicapai sebesar 69,37.

Data tersebut juga dapat dilihat melalui diagram lingkaran pada Gambar 4.3 sebagai berikut.

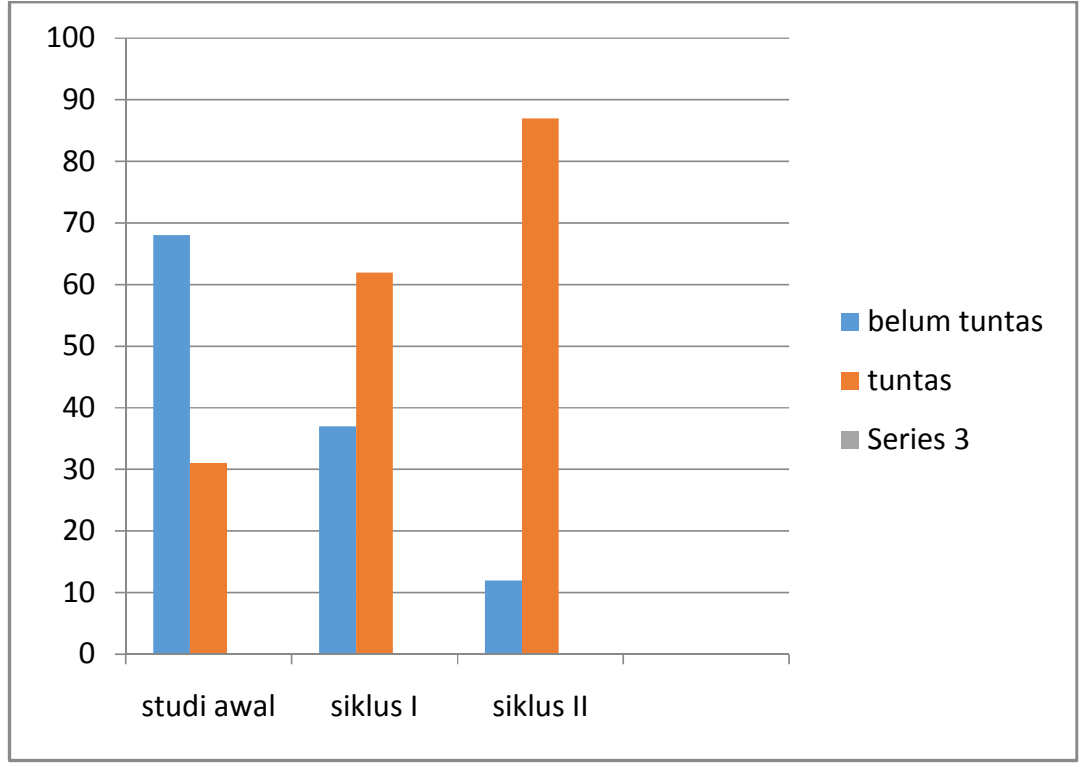

Gambar 3. Ketuntasan Hasil Prestasi Belajar Siklus II

Pada siklus II ini, ketuntasan belajar siswa dalam pembelajaran Pendidikan Agama Islam Kompetensi dasar Menyebutkan hal-hal yang membatalkan salatmelalui model Penerapan Model Pembelajaran Eksperimen mencapai 87,5\%. Hal ini sudah sesuai dengan kriteria ketuntasan yang sudah ditetapkan, yaitu minimal $80 \%$ dari jumlah siswa. Dengan demikian, peneliti dan observer sepakat untuk mengakhiri perbaikan pembelajaran pada siklus II ini.

Setelah dilakukan analisis terhadap data yang diperoleh, hasil penelitian perbaikan pembelajaran ini secara keseluruhan dapat dirangkum sebagai berikut. Berdasarkan hasil pengamatan dan pengumpulan data dari pelaksanaan perbaikan pembelajaran baik pada prasiklus, siklus I maupun siklus II dapat dilihat pada Tabel 1 di bawah ini. 
Tabel 1. Rekapitulasi Prestasi Belajar Siswa

\begin{tabular}{|l|l|l|l|l|l|}
\hline \multirow{2}{*}{ No. } & \multirow{2}{*}{ Kegiatan } & \multicolumn{2}{|l|}{ Siswa Tuntas } & \multicolumn{2}{l|}{ Siswa Belum Tuntas } \\
\cline { 3 - 6 } & & Frekuensi & \% & Frekuensi & \% \\
\hline 1. & Prasiklus & 5 & 31.25 & 11 & 68,75 \\
2. & Siklus I & 10 & 62,5 & 6 & 37,5 \\
3. & Siklus II & 14 & 87,5 & 2 & 12,5 \\
\hline
\end{tabular}

Dari Tabel 1 tentang rekapitulasi prestasi belajar siswa pada pembelajaran prasiklus, siklus I, dan siklus II dapat diperoleh keterangan sebagai berikut:

a. Pada prasiklus, jumlah siswa yang tuntas ada 5 siswa dari 16 siswa dengan persentase $31,25 \%$ dan siswa yang belum tuntas ada 11 siswa dari 16 siswa dengan persentase $68,75 \%$.

b. Pada siklus I, jumlah siswa yang tuntas ada 10 siswa dari 16 siswa dengan persentase $62,5 \%$ dan siswa yang belum tuntas ada 6 siswa dari 16 siswa dengan persentase $37,5 \%$.

c. Pada siklus II, jumlah siswa yang tuntas ada 14 siswa dari 16 siswa dengan persentase 87,5\% dan siswa yang belum tuntas ada siswa dari 16 siswa dengan persentase $12,5 \%$.

Dari Tabel 1 tentang rekapitulasi prestasi belajar siswa pada pembelajaran prasiklus, siklus I, dan siklus II sudah menunjukkan adanya peningkatan yang lebih baik, hal ini dapat dilihat pada grafik berikut.

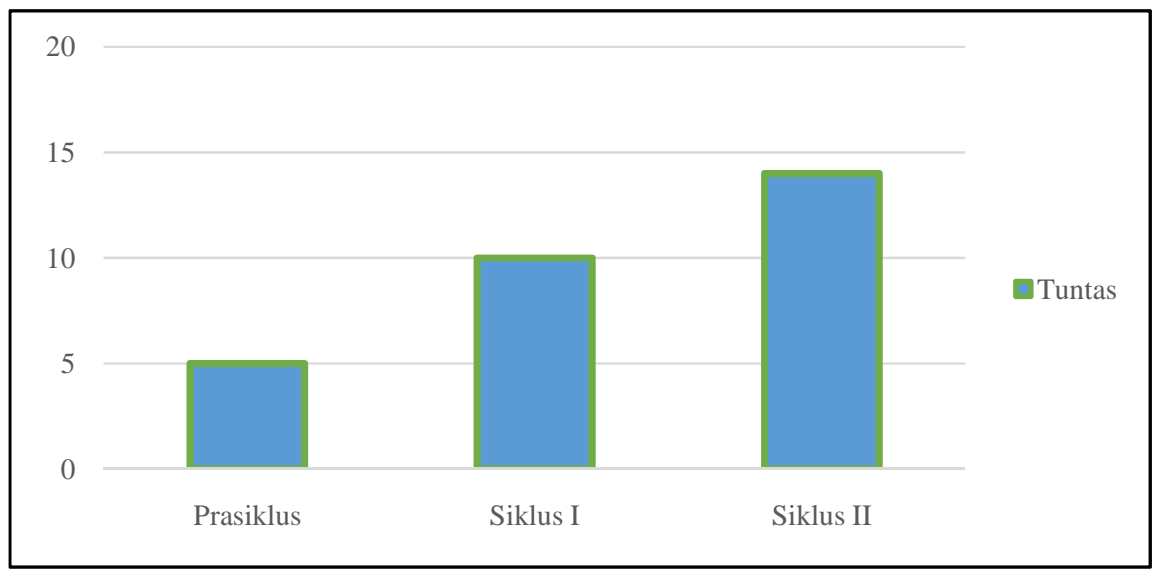

Gambar 4. Grafik Peningkatan Ketuntasan Belajar Siswa

Dari Gambar 4 tentang peningkatan ketuntasan belajar siswa dapat diterangkan bahwa pada prasiklus, jumlah siswa yang tuntas ada 5 siswa dari 16 siswa. Sedangkan pada siklus I, jumlah siswa yang tuntas ada 10 siswa dari 16 siswa. Kemudian pada siklus II, jumlah siswa yang tuntas ada 14 siswa dari 16 siswa. Dari Tabel 4 tentang rekapitulasi prestasi belajar siswa pada pembelajaran prasiklus, siklus I, dan siklus II sudah 
menunjukkan adanya penurunan yang signifikan pada siswa yang belum tuntas. Hal ini dapat dilihat pada grafik berikut ini.

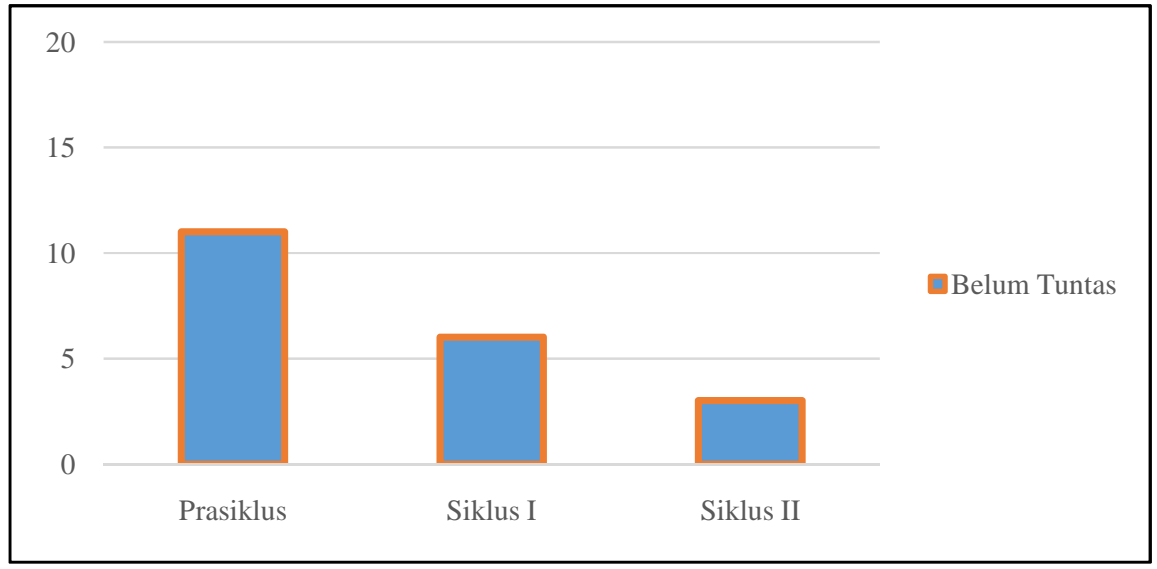

Gambar 5. Grafik Penurunan Ketidaktuntasan Belajar Siswa

Dari Gambar 5 tentang penurunan ketidaktuntasan belajar siswa dapat diterangkan bahwa pada prasiklus, jumlah siswa yang belum tuntas ada 11 siswa dari 16 siswa. Sedangkan pada siklus I, jumlah siswa yang belum tuntas ada 6 siswa dari 16 siswa. Kemudian pada siklus II, jumlah siswa yang belum tuntas ada 3 siswa dari 16 siswa. Sesuai dengan teori Martinis Yamin (2007:154) yang menyatakan bahwa "model Penerapan Model Pembelajaran Eksperimen adalah cara pembelajaran Eksperimen penggunaan alat atau melaksanakan kegiatan tertentu seperti kegiatan yang sesungguhnya". Hal ini terbukti terjadi peningkatan partisipasi siswa dalam pembelajaran model Penerapan Model Pembelajaran Eksperimen dari perbaikan pembelajaran siklus I dan siklus II.

\section{KESIMPULAN}

Berdasarkan rumusan masalah, maka peneliti menarik kesimpulan bahwa penerapan model Penerapan Model Pembelajaran Eksperimen pada mata pelajaran Pendidikan Agama Islam Kompetensi dasar Menyebutkan hal-hal yang membatalkan salat dapat meningkatkan prestasi belajar siswa kelas IV di SD Negeri Karangwangkal. Prestasi belajar siswa meningkat $31 \%$ dari kegiatan prasiklus hingga siklus I. Peningkatan prestasi belajar siswa ini terbukti pada pembelajaran prasiklus hanya ada 5 siswa atau 31,25\% yang tuntas $\geq$ KKM dan 11 siswa atau 68,75\% yang belum tuntas $\leq$ KKM. Setelah dilakukan perbaikan pembelajaran pada siklus I, prestasi belajar siswa meningkat, yaitu 10 siswa atau $62,5 \%$ yang tuntas $\geq$ KKM dan 6 siswa atau 37,5\% yang belum tuntas $\leq$ KKM. Kemudian pada siklus II, perbaikan pembelajaran melalui penelitian tindakan kelas di SD 
Negeri Karangwangkal kelas IV pada mata pelajaran Pendidikan Agama Islam

Kompetensi dasar Menyebutkan hal-hal yang membatalkan salatdengan menggunakan model Penerapan Model Pembelajaran Eksperimen hasil pembelajarannya telah berhasil karena sudah di atas kriteria ketuntasan yang ditentukan yaitu $80 \%$. Prestasi belajar siswa meningkat $25 \%$ dari kegiatan pembelajaran siklus I hingga siklus II. Peningkatan prestasi belajar ini terbukti pada pembelajaran siklus I ada 10 siswa atau $62,5 \%$ yang tuntas $\geq$ KKM dan ada 6 siswa yang belum tuntas $\leq$ KKM. Setelah dilakukan perbaikan pembelajaran pada siklus II, prestasi belajar siswa semakin meningkat, yaitu 14 siswa atau $87,5 \%$ yang tuntas $\geq \mathrm{KKM}$ dan siswa atau $12,5 \%$ yang belum tuntas $\leq \mathrm{KKM}$.

\section{SARAN}

Perlu dilakukannya berbagai penelitian tindakan melalui berbagai metode inovatif.

\section{DAFTRA PUSTAKA}

Agus Suprijono. (2012). Cooperative Learning. Yogyakarta: Pustaka Belajar.

Buchari Alma, dkk. (2010). Pembelajaran Studi Sosial. Bandung: Alfabeta.

Isjoni. (2007). Integrated Learning: Pendekatan Pembelajaran Pendidikan Agama Islam di Pendidikan SD. Bandung: Fallah Production.

Istarani. (2011). 58 Model Pembelajaran Inovatif (Referensi Guru dalam Menentukan Model Pembelajaran). Medan: Media Persada.

John M. Echols \& Hassan Shadily. (1984). Kamus Inggris-Indonesia. Jakarta: Gramedia.

Martinis Yamin. (2007). Kiat Membelajarkan Siswa. Jakarta: Gaung Persada Press.

Muhammad Numan Somantri. (2001). Menggagas Pembaharuan Pendidikan Pendidikan Agama Islam. Bandung: PPS-UPI dan Rosdakarya.

Muhibbin Syah. (1995). Psikologi Pendidikan dengan Pendekatan Baru. Bandung: Rosdakarya.

Ngalim Purwanto. (2006). Psikologi Pendidikan. Bandung: Rosdakarya.

Rusna Ristasa. (2006). Penelitian Tindakan Kelas. Tangerang: Universitas Terbuka.

Sapriya, dkk. (2006). Pembelajaran dan Evaluasi Hasil Belajar Pendidikan Agama Islam. Bandung: UPI Press. (2009). Pembelajaran dan Evaluasi

Hasil Belajar Pendidikan Agama Islam. Bandung: UPI Press. 